\title{
Clinical and Laboratory Profile of Patients With Anaphylaxis to Fire Ant Venom (Solenopsis Sp) Under Specific Subcutaneous Immunotherapy.
}

\section{Alexandra Sayuri Watanabe ( $\sim$ watanabe.ale@gmail.com )}

Sao Paulo University Faculty of Medicine: Universidade de Sao Paulo Faculdade de Medicina https://orcid.org/0000-0002-3443-0362

\section{Marcelo Alves Ferreira}

Sao Paulo University Faculty of Medicine: Universidade de Sao Paulo Faculdade de Medicina

\section{Anne Karoline Rocha Medrado Ventura}

Sao Paulo University Faculty of Medicine: Universidade de Sao Paulo Faculdade de Medicina

\section{Clóvis Eduardo Santos Galvão}

Sao Paulo University Faculty of Medicine: Universidade de Sao Paulo Faculdade de Medicina Jorge Kalil

Sao Paulo University Faculty of Medicine: Universidade de Sao Paulo Faculdade de Medicina

Keity Souza Santos

Sao Paulo University Faculty of Medicine: Universidade de Sao Paulo Faculdade de Medicina

\section{Fabio Fernandes Morato Castro}

Sao Paulo University Faculty of Medicine: Universidade de Sao Paulo Faculdade de Medicina

\section{Research Article}

Keywords: Fire Ant Venom, Immunotherapy, Anaphylaxis

Posted Date: January 3rd, 2022

DOI: https://doi.org/10.21203/rs.3.rs-909581/v1

License: (c) (1) This work is licensed under a Creative Commons Attribution 4.0 International License. Read Full License

Version of Record: A version of this preprint was published at SN Comprehensive Clinical Medicine on March 5th, 2022. See the published version at https://doi.org/10.1007/s42399-022-01150-z. 


\section{Abstract}

Anaphylaxis to fire ant venoms (Solenopsis $s p$ ) is a significant cause of systemic allergic reaction caused by Hymenoptera stings in children. There are only a few reports about the safety and efficacy of specific immunotherapy. We aim evaluate clinical characteristics, IgE and IgG4 specific responses of patients undergoing immunotherapy with a whole-body extract of Solenopsis sp after one year of the maintenance phase. Thirty-three patients were enrolled due to anaphylaxis by fire ant venom (Solenopsis $s p$ ) and underwent specific venom immunotherapy. They were assessed at baseline and one year after the beginning of the maintenance phase for skin test; specific lgE and IgG4 antibodies to fire ant venom; tryptase. All patients included presented a severe anaphylactic reaction. Although two patients $(6.25 \%)$ presented a tryptase level higher than $11.4 \mathrm{ug} / \mathrm{ml}$, systemic mastocytosis was ruled out. There was no relationship between the severity of the reaction with gender, tryptase level, atopy, previous reactions, concentration of the allergen in the skin test or specific lgE level. There was an increase of the specific $\operatorname{lgG} 4 / \lg E$ ratio between the two time points. Reactions were local, with only two mild systemic reactions during the build-up phase. Twenty patients had accidental stings during immunotherapy, with 3 presenting only urticaria. This study is unprecedented in evaluating clinical and laboratory data in the fire ant immunotherapy. Our results show that after one year of the maintenance phase, patients did not develop any severe reaction with only a few mild reactions and presented a significant production of specific IgG4.

\section{Introduction}

Bees, wasps, and ants are the Hymenoptera involved in accidents causing allergic manifestations. Bees and wasps' venoms are the most well-characterized and purified commercial extracts are available for testing and treatment in the United States and Europe, while ants are much less studied. They are biodiverse, with 22 recognized subfamilies, approximately 300 genera, and more than 14,000 species. However, only a small number of them have been described to cause allergic reactions in humans ${ }^{1}$, including the so-called imported fire ants (Solenopsis sp.) present in Brazil.

The clinical manifestations produced by Hymenoptera venom can be classified into local, large local, systemic anaphylactic and delayed systemic reactions. The risk of a person being stung in an endemic area is from $30 \%$ to $60 \%{ }^{2,3}$, with a $0.16 \%$ to $16 \%$ risk of presenting severe systemic reactions ${ }^{4,5}$.

The diagnosis of anaphylaxis to ant venom is based on clinical history, testing for specific lgE antibodies to the venom, and skin tests after at least 3 to 4 weeks after the acute event to reduce the likelihood of a false-negative result. These tests not only confirm the diagnosis but also identify the appropriate extract to be used in immunotherapy ${ }^{6}$.

Allergen-specific immunotherapy in children is indicated for the treatment of allergic rhinitis, allergic asthma, some foods, and Hymenoptera hypersensitivity ${ }^{7}$. Besides being effective in reducing subsequent 
systemic reactions in children and adults, this treatment significantly increases the quality of life (QoL) of these patients ${ }^{8}$.

The treatment is considered to be safe and effective. The reported efficacy for patients treated with bee venom is $77-84 \%$, and $91-96 \%$ for patients who received wasp venom 9,10 .

Triplett ${ }^{11}$ was the first to report successful immunotherapy with whole-body extracts for fire ant venom allergy in 1973. It is widely used in the USA by allergists ${ }^{12}$.

There were no systematic studies on the efficacy of fire ant immunotherapy with whole-body extract until Freeman et al $^{13}$ in 1992 used sting challenge to assess efficacy. They demonstrated that immunotherapy with whole-body extracts provided a high degree of protection to most patients.

Safe and effective of cluster, rush and ultra-rush schedules for fire ant immunotherapy have been previously reported. Most of the studies with a limited number of patients and the focus were mainly determined whether prophylactic pretreatment with antihistamines and steroids reduced the systemic reaction rate ${ }^{14,15,16,17,18,19,20}$.

Adams at al ${ }^{16}$ illustrated the safety and efficacy of repeated fire ant rush immunotherapy in three patients. Beveridge et al ${ }^{17}$ describe a cluster imported fire ant schedule in a 66-year-old man.

Tankersley et al ${ }^{18}$ evaluated fifty-nine patients with imported fire ant hypersensitivity randomized to placebo or twice-daily terfenadine $60 \mathrm{mg}$, ranitidine $150 \mathrm{mg}$, and prednisone $30 \mathrm{mg}$ before rush protocol in a double-blinded study. Sting challenges were performed on 56 patients, and they concluded that rush immunotherapy is safe and efficacious; the rate of mild systemic reactions was low.

Dietrich et al ${ }^{19}$ included 37 patients in a 1-day rush protocol. Twenty-two were stung challenged, $21 \mathrm{did}$ not result in any signs or symptoms of a systemic reaction, giving an efficacy rate of preventing systemic reactions of $95.5 \%$ for the rush protocol.

Arseneau et $\mathrm{al}^{20}$ evaluate the safety and efficacy of 1-day rush immunotherapy with fire ant whole-body extract $(0.5 \mathrm{~mL} \mathrm{1:100} \mathrm{(wt/vol)} \mathrm{maintenance} \mathrm{injection),} \mathrm{with} \mathrm{a} \mathrm{sting} \mathrm{challenge} \mathrm{on} \mathrm{approximately} \mathrm{day} 22$ in 66 patients.

Brown et $\mathrm{al}^{21}$ reported that venom immunotherapy with $M$ pilosula (jack jumper) was very effective in preventing life-threatening sting anaphylaxis, and it could benefit the population in areas of southeastern Australia where Myrmecia ant stings occur.

La Shell et al ${ }^{23}$ showed that three-year subcutaneous immunotherapy with whole-body extract is safe; however, specific IgE and IgG4 antibodies or tryptase before and after immunotherapy were not evaluated. 
Thus, the objective of this study was to evaluate side effects, efficacy and specific lgE and IgG4 production of patients submitted to subcutaneous fire ant immunotherapy with whole-body extracts of Solenopsis sp. during the first year of treatment.

\section{Methods}

\section{Types of participants enrolled in this study:}

Patients were attended at the ambulatory of anaphylaxis of the Clinical Immunology and Allergy Service of the Hospital das Clínicas - Faculty of Medicine - Sao Paulo University. They presented a history of a severe anaphylactic reaction (Muller's severity score: grade III or IV24) after fire ant sting of the species Solenopsis $s p$, and according to the following inclusion criteria:

- Children or adults: age 5 to 65 year

- Diagnosis of type I hypersensitivity confirmed by positive determination of specific IgE level (Solenopsis $s p$-ImmunoCap ${ }^{\circledR} \mathrm{i} 70$ ) and a positive skin test (prick or intradermal test).

- Informed consent form signed by the patient or authorized representatives approved by our institutional review board.

The following items were accepted as exclusion criteria: use of immunomodulatory treatment in the last five years; previous treatment with specific allergen immunotherapy; moderate or severe persistent asthma and FEV1 <80\%; pregnancy; illiteracy; psychiatric illness; continuous use of $\beta$-blockers; cardiovascular diseases, organ failure, and diseases that increase the risk of side effects of adrenaline and other immunological, autoimmune diseases or malignancy.

\section{Research design:}

After fulfilling the inclusion criteria, patients underwent the skin test. Prick test method were carried out with positive (histamine base) and negative (saline) controls and the following concentrations of the whole-body extract of the Solenopsis mix (HollisterStier; Spokane, USA) were utilized: 1:1,000,000 wt/vol; 1:100,000 wt/vol; 1:10,000 wt/vol; 1:1000 wt/vol, if needed. If the prick result was negative, the prick test was followed by intradermal testing. The test was considered positive when the wheal diameter was 5 $\mathrm{mm}$ or greater with a flare of $11 \mathrm{~mm}$ or greater for the prick test and for the intradermal test when the wheal enlargement was above $3 \mathrm{~mm}$ from the initial wheal caused by the volume of the injected extract and flare greater than $11 \mathrm{~mm}^{18}$.

After positivity to the skin test, the starting dose of the immunotherapy was calculated as follows: if the positivity was in the prick test, three concentrations were returned to start the treatment. If this test was positive in the intradermal test, two concentrations were returned. The protocol used for immunotherapy with whole-body extract (Solenopsis sp) was the cluster-modified schedule, whose concentrations increased weekly until the maintenance phase, which in this study was considered 1:100wt/vol, volume: 
$0.5 \mathrm{~mL}$. Maintenance doses were subsequently spaced to once every 4 weeks. The approval of the project by the Ethics Committee was signed on January 20, 2016 (Online registration $n^{0}$ : 14174). FIGURE 1 exemplifies the immunotherapy schedule in the build-up phase used with an initial hypothetical dose:

Skin testing and immunotherapy were performed with whole-body extract (HollisterStier company, Spokane, USA) that consisted of a Solenopsis invicta and Solenopsis richteri mix from a 50-mL 1:10 wt/vol stock bottle in $0.4 \%$ phenol.

The following clinical characteristics: assessment of gender, atopy, age, urban or rural area, and the following tests were performed at baseline: measurement of total $\lg \mathrm{E}, \lg \mathrm{G}, \lg \mathrm{M}$, $\lg A$ antibodies; measurement of serum IgE antibody for Solenopsis mix (i70); tryptase level, specific IgG4 antibody, and skin test.

After one year in the maintenance phase of the treatment, the following parameters were evaluated: specific lgE antibody level (i70), specific IgG4 antibody, adverse reactions to immunotherapy, accidental stings, and which were reactions that occurred in those stings.

\section{Statistics}

Categorical data were summarized using percentages and analyzed using Pearson's chi-square tests with Yates' continuity correction, Student's t-test, and ANOVA with Tukey's adjustment or Wilcoxon test, whichever most appropriate. Results were considered statistically significant for $P$ values less than 0.05 .

\section{Results}

\section{Patients}

All 33 patients enrolled in the study had histories of systemic reactions (Muller's severity score: grade III or IV) to fire ant stings and positive skin test reactions to the whole-body extract to Solenopsis mix. TABLE 1

During the treatment, when they were in the maintenance phase, three patients gave up the treatment: 2 of them reported that they had been stung twice and had no reactions, added to the difficulty of transportation. The third patient gave up for fear of losing a job.

The majority of systemic reactions (grade III or IV) to fire ants index field stings resulted from 1 sting.

\section{Possible risk factors associated with the severity of the symptoms:}

\section{Gender:}

There was no correlation between gender and the severity of the reaction (Pearson's Chi-squared test with Yates' continuity correction; $\mathrm{p}=0.9151)$. TABLE 2

\section{Atopy}


Seventeen patients (51.51\%) reported a diagnosis of allergic rhinitis and/or allergic asthma. The diagnosis of allergic rhinitis and/or asthma did not prove to be a risk factor for the severity of the reaction, as there was no relationship of this disease in patients who presented a grade IV reaction. ( $p$ value $=0.9233788)$. TABLE 2

\section{Tryptase level}

Patients with an anaphylactic reaction, grade III severity had a mean basal tryptase level of $3.63 \mathrm{ng} / \mathrm{mL}$, with a standard deviation of $3.06 \mathrm{ng} / \mathrm{mL}$. Patients with grade IV anaphylactic reaction had an average of $4.76 \mathrm{ng} / \mathrm{mL}$, with a standard deviation of $6.98 \mathrm{ng} / \mathrm{mL}$. There was no correlation between serum tryptase level and grade IV severity (Wilcoxon rank with continuity correction; $p=0.4333$ ). TABLE 2

\section{Previous reactions}

Considering only Grade-IV severe previous reactions, for natural history assessment purposes, there was no correlation with any specific reaction: $11.11 \%$ had a previous grade-II severity reaction; $22.22 \%$, GradeIV; $55.56 \%$, local and $11.11 \%$, extensive local. In these patients, there was no correlation between reaction severity in previous stings and progression to a severe reaction in future stings $(p=1.207)$. Most of the patients reported a local reaction. TABLE 2

\section{Ant fire IgE level (Immunocap i70®)}

Considering the correlation between the severity of the reaction and the measurement of specific $\lg E$ levels against fire ant (ImmunoCap i70尺), there was no statistical difference between the groups $(p=$ 0.776). Patients with a grade III severity had a mean value of $26.3 \mathrm{kU} / \mathrm{L}$, with a standard deviation: 32.4, and patients with grade IV severity had a mean value of $45.9 \mathrm{kU} / \mathrm{L}$ and standard deviation: 49.2. TABLE 2

\section{Skin test}

Patients presented the following results in the skin test (prick test and intradermal test), with most of the results being positive in the intradermal test (81.8\%), FIGURE 2.

There was no correlation between concentrations in positive skin test with the severity of the reaction presented (chi-square test; $p=0.7354)$. TABLE 2

\section{Dynamic between specific IgE and IgG4 antibodies}

\section{Fire ant IgE antibody level: basal and in the maintenance phase}

When evaluating the ratio of the specific IgE level (Immunocap $\left.\AA^{8} i 70\right)$ for each patient before and after one year in the maintenance phase, there was a statistically significant difference $(p=0.0041)$. The specific IgE antibody decreased in this interval of time in $73.3 \%$ of patients (mean baseline: $31.67 \mathrm{kU} / \mathrm{L}$; after one year in the maintenance phase: $9.86 \mathrm{kU} / \mathrm{L}$, mean). 


\section{Serum determination of specific IgG4 antibody}

Serum specific IgG4 antibody was performed at baseline and 12 months after the beginning of the maintenance phase (FIGURE 3a).

\section{Specific serum $\lg G 4 / \lg E$ ratio}

When comparing the serum $\operatorname{lgG} 4 / \mathrm{lgE}$ ratio to fire ant venom at baseline and after one year from the beginning of the maintenance phase, there was a statistically significant difference (Wilcoxon test, $p=$ 0.0000318), FIGURE 3b.

\section{Adverse reactions to immunotherapy}

\section{During the build-up phase}

During the build-up phase, two patients (6.06\%) presented grade-I reaction (only one organ involved limited to skin - mild urticaria), and four patients (36.36\%) had local reactions $>50 \mathrm{~mm}$ after subcutaneous injections. In $57.58 \%$, there was a local reaction smaller than $50 \mathrm{~mm}$ or no reaction at all.

Considering the risk of reaction in each injection applied, in 1167 applications performed during the buildup phase, with $58.33 \%$ of the reactions occurring in dose $1: 100 \mathrm{wt} / \mathrm{vol}$. The risk of systemic reaction by injection was $0.017 \%$ in this phase (FIGURE 4 ).

\section{During the maintenance phase:}

During the maintenance phase, five patients (15.15\%) presented local reactions at the injection site $>50 \mathrm{~mm}$, and $84.85 \%$ presented no reaction or had a reaction less than $50 \mathrm{~mm}$. No patient had a systemic reaction in the maintenance phase of the treatment.

When considering the risk of reaction in each injection applied, we had 5 reactions $(1,4 \%)$ in 360 applications performed during the maintenance phase, being only local reactions (FIGURE 4).

There was no need to use adrenaline at any time during treatment, and the systemic reactions that occurred in the build-up phase were treated only with antihistamines with improvement after 2 hours in the observation period.

\section{Field stings during the treatment}

During the treatment, 20 patients $(60.6 \%)$ presented accidental field stings by fire ants.

During the build-up phase, five patients were stung: four local reactions and one grade-I reaction (mild urticaria) that improved after antihistamine, with no need to seek emergency care or use adrenaline autoinjectable. FIGURE 5 
In total, patients referred nine accidental field stings because they have subsequent stings: 2 patients had experimented stings two times during the build-up phase, one patient was stung three times, and two patients had a single sting.

During one year of observation in the maintenance phase: nineteen patients (57.6\%) were accidentally stung, with seventeen patients (89.5\%) having experimented a local reaction and two patients $(10.5 \%)$ having grade-I systemic reactions: urticaria, that improved after taking an oral antihistamine, with no the need to seek emergency care or use adrenaline auto-injectable. FIGURE 5

As some patients were stung more than once, 35 accidental stings were observed during the first year of the maintenance phase. FIGURE 5

The patient 7 draws attention, he lives in a rural area, and he was accidentally stung eight times, two times in the build-up phase, and six times in the maintenance phase, with only one local reaction in all events.

Considering only the patients who had a grade IV systemic reaction in the index field sting $(n=9)$, one patient had two field stings during the build-up phase with local reaction. During the maintenance phase: three patients had field stings (one, four and two stings) with local reaction, and one patient had a single sting with a mild systemic reaction, whose hives improved after taking $20 \mathrm{mg}$ Bilastine.

\section{Discussion}

Fire ant stings are frequent in pediatric age: $32 \%$ to $54 \%$ of the surveyed population ${ }^{25}$.

In this study, systemic reactions after fire ant stings were also more prevalent in patients $(n=17)$ under 15 years $(51.51 \%)$. If we expand the age group up to 20 years old, the frequency of the systemic reactions rises to $75.9 \%$. Among Grade-IV reactions, the patient's age has not positively correlated with the grade of the sting reaction.

In literature, male sex is an independent risk factor for severe systemic reactions to the field sting. The effect of male sex in insect sting induced anaphylaxis presumably results from a selection effect.

Because of a different degree of exposure, adult men are stung more frequently than women. They might, therefore, be at higher risk for sensitization or severe allergic reactions to honeybee or wasp venom. There is no data on fire ant venom ${ }^{26}$. In this study, there was no gender influence on the severity of the reaction; there was only a slight predominance of males: $51.5 \%$ over females: $48.5 \%$, probably due to the greater exposure.

Concerning atopy, it is known that it is a risk factor for anaphylaxis triggered by food, exercise, and late ${ }^{27}$. It has not yet been established that atopic disease increases the risk of anaphylaxis associated with Hymenoptera venom allergic reaction ${ }^{28}$. 
According to an international anaphylaxis consensus (ICON) ${ }^{29}$; cardiovascular disease and uncontrolled asthma are well-recognized risk factors for severe anaphylaxis in general. In the current study, there was no correlation between asthma with a Grade-IV systemic reaction.

Considering the previous systemic reaction, in literature, $18 \%$ of the mild systemic reactions in previous stings evolved into severe systemic reactions ${ }^{30}$. In the current study, the percentage was lower, $11.11 \%$. In the same study mentioned above, a third of patients (24\%) developed the same severity as the previous reactions ${ }^{30}$; meanwhile, we obtained a percentage of $22.22 \%$, data similar to the literature.

Considering the previous large local reactions, Golden et al ${ }^{31}$ observed that $7 \%$ of children who had large local reaction progressed to a systemic reaction in subsequent stings. Graft and collaborators ${ }^{32}$ reported $2 \%$ of systemic reaction when they had large local reactions previously. Our findings showed that $11.11 \%$ of the patients had experienced a large local reaction in the previous sting. The vast majority (55.56\%) reported only local reactions in previous reactions. Therefore, in our patients, there was no correlation between having a certain severity of reaction in previous stings and subsequently evolving to a more severe reaction in subsequent stings $(p=1.207)$. The vast majority reported only a local reaction in the sting prior to anaphylaxis.

In literature, a history of large local reactions carries a lower risk of a systemic reaction than in all other sensitized patients. When a large local reaction results after bee venom, the likelihood of anaphylaxis from a future sting is approximately $5 \%$. For comparison, when there is a history of anaphylaxis from a previous Hymenoptera sting and the patient has positive skin test results to venom, at least $60 \%$ of adults and $20-32 \%$ of children will develop anaphylaxis with a future sting ${ }^{33}$. A fact that draws attention in our study is in 4 out of 18 patients, the first systemic reaction was already severe, and that these patients were not referred to a specialist for investigation. Only in the subsequent reaction, two patients were referred to a specialist for investigation, and the other two patients were not referred, looking for a specialist willingly.

Comparing the results of specific serum IgE measurements against fire ant venom with skin tests results in patients with grade-IV systemic reactions, our findings corroborate with the literature $34,35,36$ that there is no correlation between the degree of sensitization and severity of the reaction.

\section{Changes in specific IgE and IgG4 antibodies measurements}

The levels of fire ant IgE antibody decreased in the period observed in $73.3 \%$ of the patients, while specific IgG4 increased in that period. Thus, the specific lgE/lgG4 ratio at baseline and 12 months after the maintenance phase showed significant differences.

After an initial increase in the first months of treatment, specific lgE levels tend to decrease during immunotherapy ${ }^{37,38}$ and generally remain low even after discontinuation of treatment ${ }^{39}$. On the other hand, specific serum IgG4 levels increase during immunotherapy with venom ${ }^{40,41,42}$. It is known that high 
levels of specific IgG4 are positively correlated with the number of stings, previously described in beekeepers ${ }^{43,44,45}$. Thus, the specific IgG4 antibody is considered a tolerance indicator in allergic individuals because it has been suggested in the literature that these antibodies can block the interaction between the allergen and the specific IgE antibodies, thus preventing reactions with the participation of $\lg E$. These effects should be reflected in the specific $\lg E / \lg G 4$ ratio ${ }^{46,47}$. The explanation for this is due to the regulatory cell populations that form a suppressive environment: a slight decrease in the production of allergen-specific IgE and early switch to B cells to produce $\lg G 4$ and, consequently, an increase in IgG4 antibodies, which is a non-inflammatory agent in allergic disorders ${ }^{7,48}$.

\section{Serum tryptase levels}

In literature, about $80 \%$ of patients with Muller's Grade-IV reaction to Hymenoptera venoms (bees and wasps) are diagnosed with mastocytosis. In these severe reactions, $20 \%$ of patients could not show clinical signs of mastocytosis ${ }^{49}$. Bonadonna et al $^{50}$ reported a correlation between a systemic reaction to Hymenoptera sting and mast cell tryptase. Three hundred seventy-nine patients presented a history of systemic reactions after being stung by these insects, $11.6 \%$ had serum mast cell tryptase that exceeded $11.4 \mathrm{ng} / \mathrm{mL}$. In this group, the rate of anaphylaxis (Muller's grade IV) was $70.5 \%$. Blum et al ${ }^{51}$ confirmed these findings in a 5-year retrospective study, with 868 patients who had severe reactions after insect stings (758 patients had both: total IgE and baseline tryptase level above the reference values). Elevated basal tryptase $(>11.4 \mathrm{ng} / \mathrm{mL})$ was associated with severe systemic reactions $(p<0.03)$. Due to this strong association, the guidelines on allergy to Hymenoptera venoms always recommend evaluating serum tryptase for these patients.

In this study, two patients (6.25\%) presented a tryptase level higher than $11.4 \mathrm{ug} / \mathrm{ml}$; however, due to the specific investigation of hematology in our hospital, the diagnosis of Systemic Mastocytosis was ruled out. As already mentioned, in literature, there is a high correlation between severe anaphylaxis and Hymenoptera stings but being reported by bees and wasps. There is no data on fire ant venom so far.

\section{Adverse reactions during immunotherapy}

Adverse events are frequently observed when unpurified extracts are utilized, and the aqueous formulations tend to cause more local reactions than depot diluents $52,53,54$.

The main risk factors that provoke serious reactions in the literature ${ }^{55}$ were very well-reviewed at each patient visit and controlled in this study: dosage error, administration of the injection without supervision by a trained professional, presence of uncontrolled asthma, the high degree of sensitivity, concomitant use of $\beta$-blockers, systemic reactions prior to immunotherapy and use of lots with new products.

When a local reaction was greater than $50 \mathrm{~mm}$, patients were instructed to use fexofenadine $180 \mathrm{mg}$ (adults), and for children, the dose was adjusted according to the weight presented. Only one adult patient took the oral antihistamine because she had a bother local reaction; other patients did not need the medication. 
In a multicenter study ${ }^{56}$ evaluating data from 840 patients, side effects of immunotherapy (systemic reactions) with venom (seventy-one percent were treated with Vespula-venom extract and $27 \%$ with honeybee-venom extract) were observed in a total of $20 \%$ of patients; 26,601 injections in 840 patients, systemic reactions were observed in $1.9 \%$ of the injections during the build-up phase and in $0.5 \%$ the maintenance phase $(p<0.05)$. Most of these reactions were mild, and only a third of patients required medical treatment. A similar frequency of systemic adverse effects was observed in a published study analyzing data from 178 patients ${ }^{57}$. The build-up phase of venom immunotherapy has more adverse effects than the maintenance phase.

In our study, the systemic reaction rate during immunotherapy was lower than the literature, comparing extracts of honeybee or wasp venoms. Our results showed a systemic reaction in $6.06 \%$ during the buildup phase. It was also lower when compared by injection $(0.017 \%)$. In the maintenance phase, there were no systemic reactions. The similarity remained in the slight severity of these reactions.

Thus, the severity of side effects due to immunotherapy does not necessarily correlate with the severity of the treated allergic disease symptoms. Systemic reactions induced by venom immunotherapy may occur, but most patients tolerate this treatment without relevant side effects.

\section{Accidental Field stings}

Reaction evaluation after a sting during or after the treatment (either by a challenge test with culprit insect or by accidental sting) is an available method to determine the degree of response to venom immunotherapy ${ }^{58}$.

When the challenge test with culprit insect was performed in a series of patients undergoing immunotherapy with bee and wasp venom, about 75 to $85 \% 8,59,60$ or even more $95 \% 61,62$ of patients were protected.

Arseneau at el ${ }^{20}$ evaluated 66 patients submitted to 1-day rush immunotherapy protocol using fire ant whole-body extract, and the conclusion was that the immunotherapy was efficacious ( 1 of 53 confirmed fire ant sting challenges (1.9\%) resulted in a reaction) and had a low rate of systemic reactions.

In Brazil, for ethical reasons, we could not perform the provocation test with the culprit insect; it is possible only to observe reactions by accidental stings during treatment.

In this study, 20 patients were stung, 35 stings in total, as some of them were stung more than once.

During the build-up phase, the patient still has an increased chance of having systemic reactions if he is stung at that moment. The patient who had a systemic reaction in the build-up phase in our study had a mild reaction (only hives, with no need to seek immediate attention or use adrenaline auto-injectable). Thus, we had one systemic reaction (in an accidental sting), out of 5 patients stung during this phase: $20 \%$ treatment failure. 
During the maintenance phase, two patients were accidentally stung. They had systemic reactions $(10.5 \%)$ and described as mild reactions: only hives, without the need to seek emergency care or the use of an adrenaline auto-injectable.

The percentage of reactions in the maintenance phase $(10.5 \%)$ is lower than the percentage found in the literature, which considers approximately a $25 \%$ risk of a new generalized systemic reaction in subsequent stings in patients who received venom immunotherapy for 1 or 2 years $^{63}$.

The optimal length of treatment with fire ant immunotherapy is not known. The treatment with fire ant immunotherapy commonly used often is 3-5 years based on extrapolation from flying Hymenoptera immunotherapy data. A 3- to 5-year course of flying Hymenoptera (e.g., honey bee, hornet, wasp, and yellow jacket) venom immunotherapy has been shown to provide protection against systemic reactions ${ }^{64}$.

Forester et $\mathrm{al}^{65}$ grouped patients into those who received $<3$ years (reduced course) and those who received $>3$ years (complete course) of imported fire ant immunotherapy (IFA). All subjects on IFA immunotherapy received a maintenance dose of $0.5 \mathrm{~mL}$ of a 1:100 w/v concentration of IFA whole-body extract. No difference in the incidence or severity of systemic reactions to field stings after immunotherapy discontinuation for the two groups studied. The systemic reaction rate was low for both the complete and the reduced course groups ( 7 and $6 \%$, respectively) after discontinuation of IFA immunotherapy.

Our patients will be in immunotherapy for 3 years. After this period, new data will be gathered.

\section{Conclusion}

Few studies have evaluated patients undergoing fire ant immunotherapy with whole-body extracts. Our study is unprecedented in the evaluation of clinical and laboratory data on these treatments.

The development of peripheral tolerance is the primary mechanism of immunotherapy. In this study, we verified a significant difference at the baseline and after one year of the maintenance phase in a specific $\operatorname{lgE} / \operatorname{lgG} 4$ ratio, reinforcing the hypothesis that the IgG4 antibody has a mode of action "blocking" the specific lgE. It is important to note that allergen-specific IgG can interfere not only in elucidating allergic responses triggered by IgE in effectors but also in presenting antigen IgE-mediated to $\mathrm{T}$ cells. It may be essential to decrease the responses of allergen-specific TH2 cells. It is essential to consider not only the individual values of each antibody but the ratio between them at baseline and during immunotherapy. In this aspect, it would be interesting to obtain further studies on specific T cells' behavior during immunotherapy with fire ant venom.

The maintenance dose of $0.5 \mathrm{~mL}$ in the concentration 1: $100 \mathrm{wt} / \mathrm{vol}$ (Hollister Stier, USA) of a mixture of whole-body extract of Solenopsis invicta and richteri was effective because of the 20 patients accidentally stung during the treatment (1 year of maintenance dose), two patients (10.5\%) had a 
systemic reaction (urticaria), with improvement after taking an oral antihistamine. Adverse reactions to immunotherapy were rare.

The lessons learned in this study should help to improve both the effectiveness and the maintenance of tolerance to fire ant immunotherapy. This treatment proved to be safe and effective.

Patients will complete treatment for three years from the maintenance dose, and patients will be followed up after discontinuation of treatment.

\section{Declarations}

Funding 'Not applicable'

Conflicts of interest/Competing interests The authors declare that they have no conflicts of interests to disclose.

Availability of data and material (data transparency)

Code availability (software application or custom code)

Funding 'Not applicable'

Conflicts of interest/Competing interests The authors declare that they have no conflicts of interests to disclose.

Ethics approval, consent to participate: Informed consent form signed by the patient or authorized representatives approved by our institutional review board (CAPpesq: online register: 14174 (sep 17th,2015)

Consent for publication all authors consent for publication

Availability of data and material all data and material are available

\section{References}

1. Golden DBK. Insect allergy. In: Adkinson NF Jr, Bochner BS, Busse WW, Holgate ST, Lemanske RF, Simons FER, editors. Adkinson: Middleton's Allergy: Principles and Practice. 8th ed. Philadelphia: Mosby Elsevier; 2014. p.1260-72 (p. 1261, Table 78-1).

1. deShazo RD, Butcher BT, Banks WA. Reactions to the stings of the imported fire ant. N Engl J Med. 1990;323:462-6.

2. deShazo RD, Williams DF, Moak ES. Fire ant attacks on residents in health care facilities: a report of two cases. Ann Intern Med. 1999;131:424-9.

3. Stafford CT. Hypersensitivity to fire ant venom. Ann Allergy Asthma Immunol. 1996;77:87-95. 
4. Triplett RF. The imported fire ant: health hazard or nuisance? South Med J. 1976;69:258-9.

5. Bilo BM, Rueff F, Mosbech H, Bonifazi F, Oude-Elberink JN. Diagnosis of Hymenoptera venom allergy. Allergy. 2005 Nov;60(11):1339-49.

6. Alvaro-Lozano M, Akdis CA, Akdis M, Alviani C, Angier E, Arasi S, Arzt-Gradwohl L, Barber D, Bazire R, Cavkaytar O, Comberiati P, Dramburg S, Durham SR, Eifan AO, Forchert L, Halken S, Kirtland M, Kucuksezer UC, Layhadi JA, Matricardi PM, Muraro A, Ozdemir C, Pajno GB, Pfaar O, Potapova E, Riggioni C, Roberts G, Rodríguez Del Río P, Shamji MH, Sturm GJ, Vazquez-Ortiz M. EAACl Allergen Immunotherapy User's Guide. Pediatr Allergy Immunol. 2020 May;31 Suppl 25:1-101. doi: 10.1111/pai.13189. PMID: 32436290.

7. Dhami S, Zaman H, Varga EM, Sturm GJ, Muraro A, Akdis CA, et al. Allergen immunotherapy for insect venom allergy: a systematic review and meta-analysis. Allergy 2017; 72:342-65.

8. Muller U, Helbling A, Berchtold E. Immunotherapy with honeybee venom and yellow jacket venom is different regarding efficacy and safety. J Allergy Clin Immunol 1992; 89:529-35.

9. Ruëff F, Vos B, Oude Elberink J, Bender A, Chatelain R, Dugas-Breit S, Horny HP, Küchenhoff H, Linhardt A, Mastnik S, Sotlar K, Stretz E, Vollrath R, Przybilla B, Flaig M. Predictors of clinical effectiveness of Hymenoptera venom immunotherapy. Clin Exp Allergy. 2014;44(5):736-46. doi: 10.1111/cea.12275. PMID: 24447114.

10. Triplett RF. Sensitivity to the imported fire ant: successful treatment with immunotherapy. South Med J. 1973 Apr;66(4):477-80. doi: 10.1097/00007611-197304000-00019. PMID: 4708246.

11. Stafford CT, Rhoades RB, Bunker-Soler AL,Thompson WO, Impson BS, Survey of whole-body extract immunotherapy for imported fire ant and other Hymenoptera sting allergy, J Allergy Clin Immunol 1989: 83: 1107-11.

12. Freeman TM, Hylander R, Ortiz A, Martin ME. Imported Fire Ant Immunotherapy: Effectiveness of Whole Body Extracts. J Allergy Clin Immunol. 1992 Aug;90(2):210-5. doi: 10.1016/00916749(92)90073-b.

13. Duplantier JE, Freeman TM, Bahna SL, Good RA, Sher MR. Successful rush immunotherapy for anaphylaxis to imported fire ants. J Allergy Clin Immunol. 1998;101(6 Pt 1):855-856. doi:10.1016/s0091-6749(98)70318-5.

14. Judd CA, Parker AL, Meier EA, Tankersley MS. Successful administration of a 1-day imported fire ant rush immunotherapy protocol. Ann Allergy Asthma Immunol. 2008;101(3):311-315. doi:10.1016/S1081-1206(10)60497-8.

15. Adams KE, Johnson KS. Safety of Repeated Imported Fire Ant Ultra-Rush Protocols. Mil Med. 2019;184(5-6):e483-e485. doi:10.1093/milmed/usy275

16. Beveridge GB, Tankersley MS. Successful completion of an imported fire ant cluster immunotherapy protocol. Ann Allergy Asthma Immunol. 2019;123(1):95-96. doi:10.1016/j.anai.2019.04.017

17. Tankersley MS, Walker RL, Butler WK, Hagan LL, Napoli DC, Freeman TM. Safety and efficacy of an imported fire ant rush immunotherapy protocol with and without prophylactic treatment. J Allergy Clin Immunol. 2002;109(3):556-562. DOI:10.1067/mai.2002.121956 
18. Dietrich JJ, Moore LM, Nguyen S, Hagan LL, Tankersley MS. Imported fire ant hypersensitivity: a 1day rush immunotherapy schedule without premedication. Ann Allergy Asthma Immunol. 2009 Dec;103(6):535-6. doi: 10.1016/S1081-1206(10)60271-2. PMID: 20084848.

19. Arseneau AM, Nesselroad TD, Dietrich JJ, Moore LM, Nguyen S, Hagan LL, Tankersley MS. A 1-day imported fire ant rush immunotherapy schedule with and without premedication. Ann Allergy Asthma Immunol. 2013 Dec;111(6):562-6. doi: 10.1016/j.anai.2013.08.021. Epub 2013 Sep 18. PMID: 24267369.

20. Brown SG, Wiese MD, Blackman KE, Heddle RJ. Ant venom immunotherapy: a double-blind, placebocontrolled, crossover trial. Lancet. 2003;361(9362):1001-1006. doi:10.1016/S0140-6736(03)12827-9

21. Wauters RH, Brooks DI, Schwartz DJ. Imported fire ant immunotherapy prescribing patterns in a large health care system during an 11-year period. Ann Allergy Asthma Immunol. 2020 Nov;125(5):577-580. doi: 10.1016/j.anai.2020.06.013. Epub 2020 Jun 13. PMID: 32544534.

22. La Shell MS, Calabria CW, Quinn JM. Imported fire ant field reaction and immunotherapy safety characteristics: the IFACS study. J Allergy Clin Immunol. 2010;125(6):1294-1299. doi:10.1016/j.jaci.2010.02.041.

23. Mueller HL. Diagnosis and treatment of insect sensitivity. J Asthma Res 1996;3:331-3.

24. Stablein JJ, Lackey RF. Adverse reactions to ant stings. Clin Rev Allergy 1987;5:161.

25. Fehr D, Micaletto $S$, Moehr T, Schmid-Grendelmeier P. Risk factors for severe systemic sting reactions in wasp (Vespula spp.) and honeybee (Apis mellifera) venom allergic patients. Clin Transl Allergy. 2019 Oct 11;9:54. doi: 10.1186/s13601-019-0292-5. PMID: 31632639; PMCID: PMC6788055.

26. Shaker MS, Wallace DV, Golden DBK, Oppenheimer J, Bernstein JA, Campbell RL, Dinakar C, Ellis A, Greenhawt M, Khan DA, Lang DM, Lang ES, Lieberman JA, Portnoy J, Rank MA, Stukus DR, Wang J; Collaborators, Riblet N, Bobrownicki AMP, Bontrager T, Dusin J, Foley J, Frederick B, Fregene E, Hellerstedt S, Hassan F, Hess K, Horner C, Huntington K, Kasireddy P, Keeler D, Kim B, Lieberman P, Lindhorst E, McEnany F, Milbank J, Murphy H, Pando O, Patel AK, Ratliff N, Rhodes R, Robertson K, Scott H, Snell A, Sullivan R, Trivedi V, Wickham A; Chief Editors, Shaker MS, Wallace DV; Workgroup Contributors, Shaker MS, Wallace DV, Bernstein JA, Campbell RL, Dinakar C, Ellis A, Golden DBK, Greenhawt M, Lieberman JA, Rank MA, Stukus DR, Wang J; Joint Task Force on Practice Parameters Reviewers, Shaker MS, Wallace DV, Golden DBK, Bernstein JA, Dinakar C, Ellis A, Greenhawt M, Horner C, Khan DA, Lieberman JA, Oppenheimer J, Rank MA, Shaker MS, Stukus DR, Wang J. Anaphylaxis-a 2020 practice parameter update, systematic review, and Grading of Recommendations, Assessment, Development and Evaluation (GRADE) analysis. J Allergy Clin Immunol. 2020 Apr;145(4):1082-1123. doi: 10.1016/j.jaci.2020.01.017. Epub 2020 Jan 28. PMID: 32001253.

27. Shaker MS, Wallace DV, Golden DBK, Oppenheimer J, Bernstein JA, Campbell RL, Dinakar C, Ellis A, Greenhawt M, Khan DA, Lang DM, Lang ES, Lieberman JA, Portnoy J et al. Anaphylaxis-a 2020 practice parameter update, systematic review, and Grading of Recommendations, Assessment, Development and Evaluation (GRADE) analysis. J Allergy Clin Immunol. 2020 January 28. pii: S00916749(20)30105-6. doi: 10.1016/j.jaci.2020.01.017. [Epub ahead of print] 
28. Simons FE, Ardusso LR, Bilo MB, Cardona V, Ebisawa M, El-Gamal YM, et al. International consensus on (ICON) anaphylaxis. The World Allergy Organization journal. 2014;7(1):9.

29. Fernandez J, Soriano V, Mayorga L, Mayor M. Natural history of Hymenoptera venom allergy in Eastern Spain. Clin Exp Allergy. 2005 Feb;35(2):179-85.

30. Golden DB, Kagey-Sobotka A, Norman PS, Hamilton RG, Lichtenstein LM. Outcomes of allergy to insect stings in children, with and without venom immunotherapy. N Engl J Med. 2004 Aug 12;351(7):668-74. doi: 10.1056/NEJMoa022952. PMID: 15306668.

31. Graft DF, Schuberth KC, Kagey-Sobotka A, Kwiterovich KA, Niv Y, Lichtenstein LM, Valentine MD. A prospective study of the natural history of large local reactions after Hymenoptera stings in children. J Pediatr. 1984 May;104(5):664-8. doi: 10.1016/s0022-3476(84)80940-3. PMID: 6716215.

32. Ochfeld EN, Greenberger PA. Stinging insect allergy and venom immunotherapy. Allergy Asthma Proc. 2019;40(6):372-375. doi:10.2500/aap.2019.40.4250

33. Sturm GJ, Kranzelbinder B, Schuster C, Sturm EM, Bokanovic D, Vollmann J, et al. Sensitization to Hymenoptera venoms is common, but systemic sting reactions are rare. J Allergy Clin Immunol. 2014;133(6):1635-43.

34. Warrington R. Lack of Correlation between Severity of Clinical Symptoms, Skin Test Reactivity, and Radioallergosorbent Test Results in Venom Allergic Patients. Allergy Asthma Clin Immunol. 2006;2(2):62-7.

35. Sturm GJ, Heinemann A, Schuster C, Wiednig M, Groselj-Strele A, Sturm EM, et al. Influence of total IgE levels on the severity of sting reactions in Hymenoptera venom allergy. Allergy. 2007;62(8):8849.

36. Urbanek R, Kemeny DM, Richards D. Sub-class of IgG anti-bee venom antibody produced during bee venom immunotherapy and its relationship to long-term protection from bee stings and following termination of venom immunotherapy. Clin Allergy. 1986;16:317-322.

37. Rueff F, Wolf H, Schnitker J, Ring J, Przybilla B. Specific immunotherapy in honeybee venom allergy: a comparative study using aqueous and aluminium hydroxide adsorbed preparations. Allergy. 2004;59:589-595.

38. van Halteren HK, van der Linden PW, Burgers JA, Bartelink AK. Discontinuation of yellow jacket venom immunotherapy: follow-up of 75 patients by means of deliberate sting challenge. J Allergy Clin Immunol. 1997;100:767-770.

39. Ewan PW, Deighton J, Wilson AB, Lachmann PJ. Venom-specific IgG antibodies in bee and wasp allergy: lack of correlation with protection from stings. Clin Exp Allergy. 1993;23:647-660.

40. Golden DB, Lawrence ID, Hamilton RH, Kagey-Sobotka A, Valentine MD, Lichtenstein LM. Clinical correlation of the venom-specific lgG antibody level during maintenance venom immunotherapy. $J$ Allergy Clin Immunol. 1992;90:386-393.

41. Wilson AB, Deighton J, Lachmann PJ, Ewan PW. A comparative study of IgG subclass antibodies in patients allergic to wasp or bee venom. Allergy. 1994;49:272-280.

42. Eich-Wanger C, Muller UR. Bee sting allergy in beekeepers. Clin Exp Allergy. 1998;28:1292-1298. 
43. Chliva C, Aggelides X, Makris M, Katoulis A, Rigopoulos D, Tiligada E. Comparable profiles of serum histamine and IgG4 levels in allergic beekeepers. Allergy. 2015;70:457-460.

44. Hayashi $Y$, Hirata $H$, Watanabe $M$, et al. Usefulness of specific-lgG4 to Hymenoptera venom in the natural history of Hymenoptera stings. J Investig Allergol Clin Immunol. 2014;24:192-194.

45. W€urtzen PA, Lund G, Lund K, Arvidsson M, Rak S, Ipsen H. A double-blind placebo-controlled birch allergy vaccination study II: correlation between inhibition of IgE binding, histamine release and facilitated allergen presentation. Clin Exp Allergy 2008;38:1290-301.

46. Ejrnaes AM, Svenson M, Lund G, Larsen JN, Jacobi H. Inhibition of rBet v 1-induced basophil histamine release with specific immunotherapy-induced serum immunoglobulin $\mathrm{G}$ : no evidence that FcgammaRIIB signaling is important. Clin Exp Allergy 2006;36:273-82.

47. Kucuksezer UC, Ozdemir $C$, Akdis M, Akdis CA. Mechanisms of immune tolerance to allergens in children. Korean Journal of pediatrics. 2013;56(12):505-513.

48. Przybilla B, Ruëff F. Hymenoptera venom allergy. J Dtsch Dermatol Ges. 2010 Feb;8(2):114-27; quiz 128-30. doi: 10.1111/j.1610-0387.2009.07125.x. Epub 2009 September 14.

49. Bonadonna P, Perbellini O, Passalacqua G, et al. Clonal mast cell disorders in patients with systemic reactions to Hymenoptera stings and increased serum tryptase levels. J Allergy Clin Immunol. 2009;123:680-686.

50. Blum S, Gunzinger A, Muller UR, Helbling A. Influence of total and specific IgE, serum tryptase, and age on severity of allergic reactions to Hymenoptera stings. Allergy 2011;66:222-228

51. Bilò MB, Antonicelli L, Bonifazi F. Purified vs. nonpurified venom immunotherapy. Curr Opin Allergy Clin Immunol. 2010 Aug;10(4):330-6. doi: 10.1097/ACl.0b013e328339f2d1. PMID: 20410817.

52. Bilò MB, Severino M, Cilia M, Pio A, Casino G, Ferrarini E, Campodonico P, Milani M. The VISYT trial: Venom Immunotherapy Safety and Tolerability with purified vs nonpurified extracts. Ann Allergy Asthma Immunol. 2009 Jul;103(1):57-61. doi: 10.1016/S1081-1206(10)60144-5. PMID: 19663128.

53. Bilò MB, Cinti B, Brianzoni MF, Braschi MC, Bonifazi M, Antonicelli L. Honeybee venom immunotherapy: a comparative study using purified and nonpurified aqueous extracts in patients with normal Basal serum tryptase concentrations. J Allergy (Cairo). 2012;2012:869243. doi: 10.1155/2012/869243. Epub 2012 Jan 12. PMID: 22287975; PMCID: PMC3263618.

54. Cox L, Larenas-Linnemann D, Lockey RF, Passalacqua G. Speaking the same language: The World Allergy Organization Subcutaneous Immunotherapy Systemic Reaction Grading System. J Allergy Clin Immunol. 2010 Mar;125(3):569-74, 574.e1-574.e7. doi: 10.1016/j.jaci.2009.10.060. Epub 2010 Feb 7. PMID: 20144472.

55. Mosbech $\mathrm{H}$, Muller U. Side-effects of insect venom immunotherapy: results from an EAACl multicenter study. European Academy of Allergology and Clinical Immunology. Allergy, 2000; 55:1005-1010.

56. Wenzel J, Meissner-Kraemer M, Bauer R, et al. Safety of rush insect venom immunotherapy. The results of a retrospective study in 178 patients. Allergy 2003; 58:1176-1179. 
57. Rueff F, Przybilla B, Muller U, Mosbech H. The sting challenge test in Hymenoptera venom allergy. Allergy 1996; 51:216-225.

58. Haeberli G, Bronnimann M, Hunziker T, Muller U. Elevated basal serum tryptase and hymenoptera venom allergy: relation to severity of sting reactions and to safety and efficacy of venom immunotherapy. Clin Exp Allergy 2003;33:1216-1220.

59. Rueff $F$, Wolf $H$, Schnitker $J$, et al. Specific immunotherapy in honeybee venom allergy: A comparative study using aqueous and aluminium hydroxide adsorbed preparations. Allergy 2004; 59:589-595.

60. Golden DBK, Kagey-Sobotka A, Valentine MD, Lichtenstein LM. Dose dependence of Hymenoptera venom immunotherapy. J Allergy Clin Immunol 1981; 67:370-374.

61. Urbanek R, Forster J, Kuhn W, Ziupa J. Discontinuation of bee venom immunotherapy in children and adolescents. J Pediatr 1985; 107:367-371.

62. Golden DBK, Johnson K, Addison BI, Valentine MD, KageySobotka A, Lichtenstein LM. Clinical and immunologic observations in patients who stop venom immunotherapy. J Allergy Clin Immunol 1986;77:435-42.

63. Golden DB, Demain J, Freeman T, et al. Stinging insect hypersensitivity: A practice parameter update 2016. Ann Allergy Asthma Immunol. 2017;118(1):28-54. doi:10.1016/j.anai.2016.10.031.

64. Forester JP, Johnson TL, Arora R, Quinn JM. Systemic reaction rates to field stings among imported fire ant-sensitive patients receiving $>3$ years of immunotherapy versus $<3$ years of immunotherapy. Allergy Asthma Proc. 2007;28(4):485-488. doi:10.2500/aap.2007.28.3021.

\section{Tables}

TABLE 1: Demographics and clinical features of the patients: 


\begin{tabular}{|c|c|}
\hline $\begin{array}{l}\text { Age, years: } \\
\text { - Between } 5 \text { to } 10 \text { years } \\
\text { - Between } 11 \text { to } 20 \text { years } \\
\text { - Between } 21 \text { to } 30 \text { years } \\
\text { - Between } 31 \text { to } 40 \text { years } \\
\text { - > } 41 \text { years }\end{array}$ & $\begin{array}{l}7 \text { - } 52 \text { years: } \\
\text { - } 6 \text { patients }(18,3 \%) \\
\text { - } 19 \text { patients }(57,6 \%) \\
\text { - } 4 \text { patients }(12,1 \%) \\
\text { - } 2 \text { patients }(6,0 \%) \\
\text { - } 2 \text { patients }(6,0 \%)\end{array}$ \\
\hline Urban area & 31 patients $(93,3 \%)$ \\
\hline Male & 17 patients $(51,5 \%)$ \\
\hline Asthma & 7 patients $(21,2 \%)$ \\
\hline $\begin{array}{l}\text { Tryptase level } \\
\text { - Reaction grade III (mean value) } \\
\text { - Reaction grade IV (mean value) } \\
\text { - }>11,4 \mathrm{ng} / \mathrm{mL}\end{array}$ & $\begin{array}{l}\text { - } 3,63 \mathrm{ng} / \mathrm{mL} \\
\text { - } 4,76 \mathrm{ng} / \mathrm{mL} \\
\text { - } 2 \text { patients* }\end{array}$ \\
\hline $\begin{array}{l}\text { Grading system* } \\
\text { - Grade III } \\
\text { - Grade IV }\end{array}$ & $\begin{array}{l}\text { - } 24 \text { patients }(72,7 \%) \\
\text { - } 9 \text { patients }(27,3 \%)\end{array}$ \\
\hline $\begin{array}{l}\text { Index field reactions } \\
\text { - Grade III }\end{array}$ & $\begin{array}{l}1 \text { sting: } 23 \text { patients }(69,70 \%) \\
5 \text { stings: } 1 \text { patient }(3,03 \%)\end{array}$ \\
\hline - Grade IV & $\begin{array}{l}1 \text { sting: } 7 \text { patients }(21,21 \%) \\
2 \text { stings: } 1 \text { patient }(3,03 \%) \\
3 \text { stings: } 1 \text { patient }(3,03 \%\end{array}$ \\
\hline
\end{tabular}

* Patients were referred to the hematology sector, with systemic mastocytosis ruled out.

**Systemic reactions measured using the Mueller grading system

TABLE 2: Baseline clinical and laboratory characteristics of the patients 


\begin{tabular}{|c|c|c|c|}
\hline $\begin{array}{l}\text { Clinical and laboratory characteristics of the } \\
\text { patients }\end{array}$ & Grade III & Grade IV & p-value \\
\hline \multirow{2}{*}{$\begin{array}{ll}\text {-. } & \text { Male } \\
\bullet & \text { Female }\end{array}$} & 12 patients $(75 \%)$ & 4 patients $(25 \%)$ & \multirow[t]{2}{*}{0.9151} \\
\hline & $\begin{array}{l}11 \text { patients } \\
(64,7 \%)\end{array}$ & $\begin{array}{l}6 \text { patients } \\
(35,3 \%)\end{array}$ & \\
\hline - Asthma & $\begin{array}{l}5 \text { patients } \\
(15,15 \%)\end{array}$ & $\begin{array}{l}2 \text { patients } \\
(6,06 \%)\end{array}$ & 0.9233788 \\
\hline - Tryptase level (mean value) & $3.63 \mathrm{ng} / \mathrm{mL}$ & $4,76 \mathrm{ng} / \mathrm{mL}$ & 0.4333 \\
\hline - Ant fire lgE level (mean value) & $26.3 \mathrm{kU} / \mathrm{L}$ & $45.9 \mathrm{kU} / \mathrm{L}$ & 0.776 \\
\hline \multicolumn{4}{|l|}{ - Skin test } \\
\hline Prick test & $\begin{array}{l}4 \text { patients } \\
(12,12 \%)\end{array}$ & $\begin{array}{l}2 \text { patients } \\
(6,06 \%)\end{array}$ & 0.7354 \\
\hline Intradermal test & $\begin{array}{l}20 \text { patients } \\
(60,06 \%)\end{array}$ & $\begin{array}{l}7 \text { patients } \\
(21,21 \%)\end{array}$ & \\
\hline
\end{tabular}

\section{Figures}

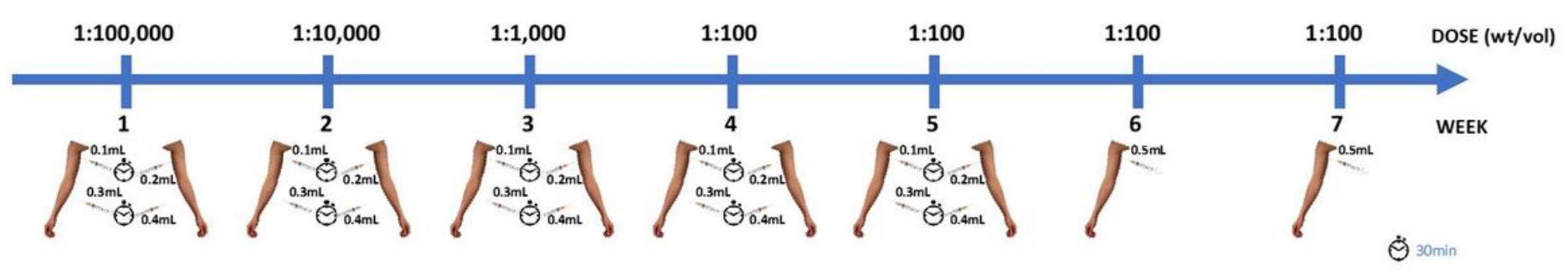

\section{Figure 1}

Build-up phase of immunotherapy using a hypothetical initial dose. Intervals between injections are of 30 minutes. 


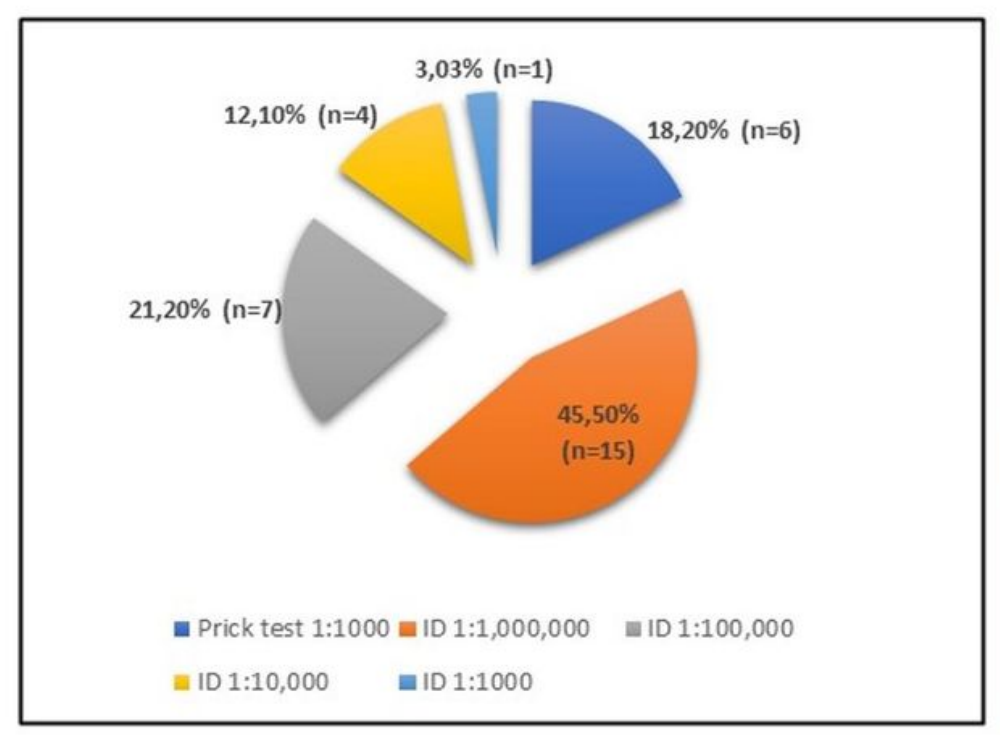

(a)

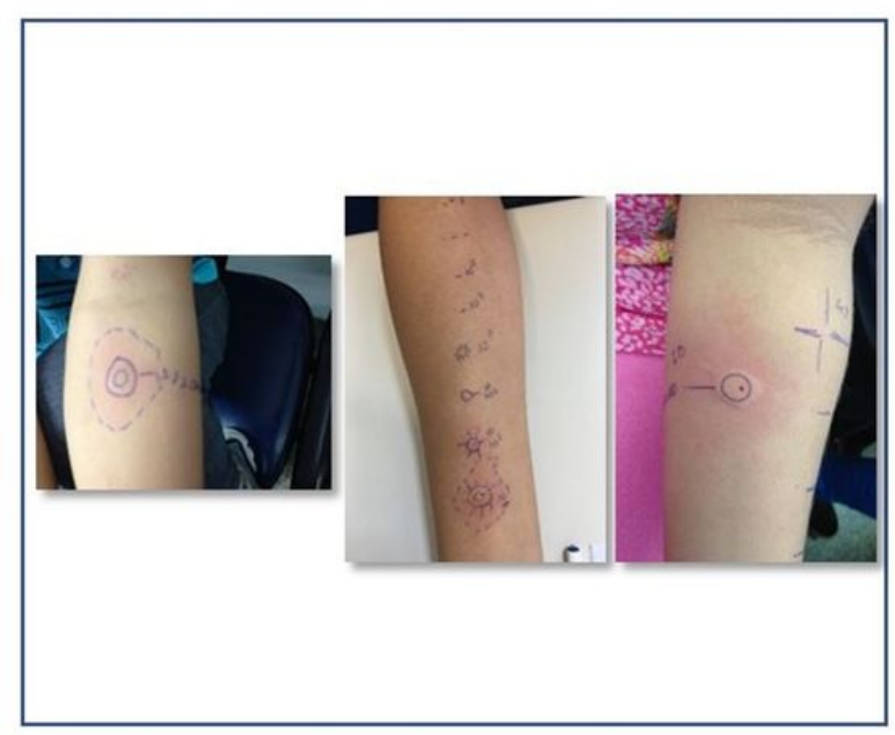

(b)

\section{Figure 2}

(a) Percentage and number of patients ( $n$ ) of positive skin tests (prick test and intradermal test)

(b) examples of positive skin tests (outpatients Anaphylaxis of HC-FMUSP) 
a

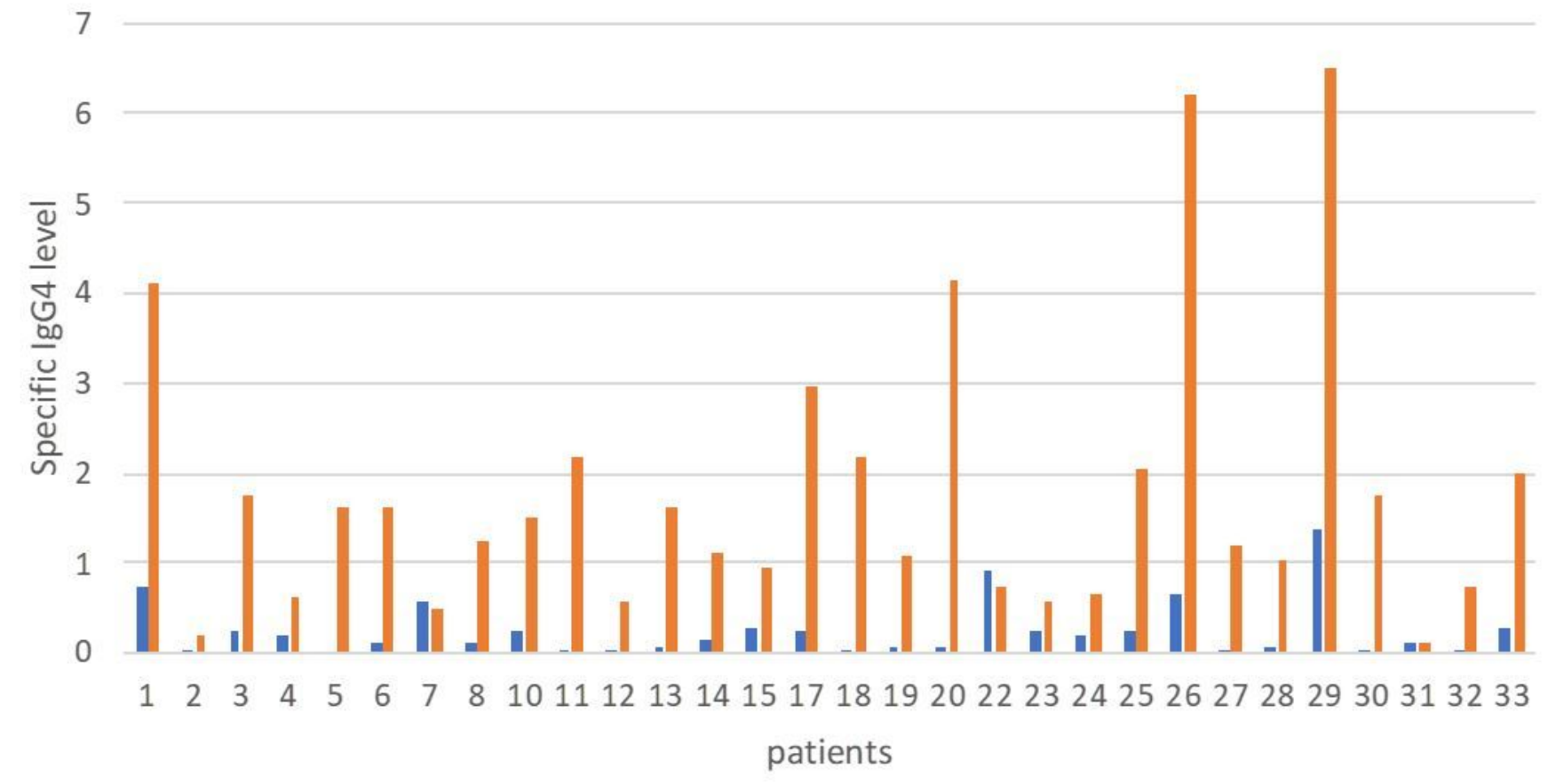

b

- Basal maintenance phase

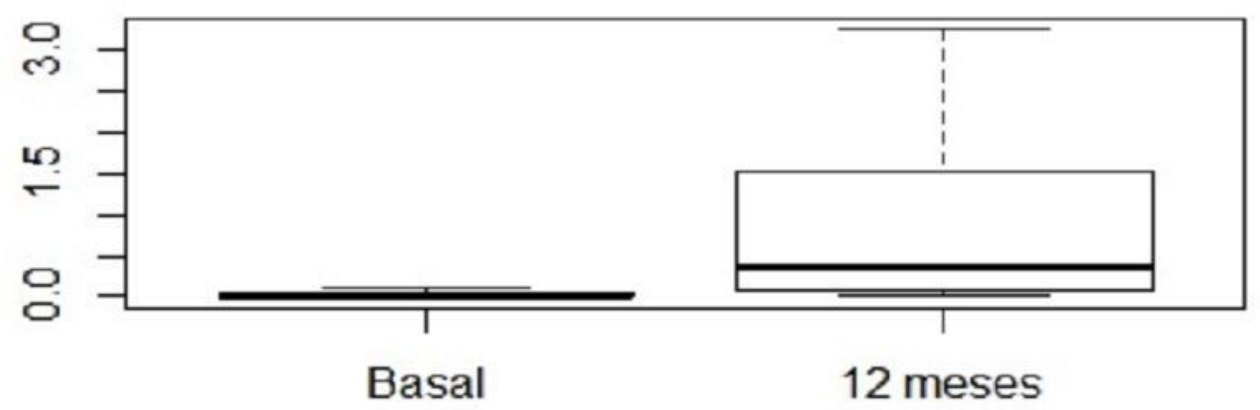

Figure 3

a) Specific IgG4 at baseline and after 12 months of immunotherapy maintenance phase $(n=30)$. b) Comparison of the ratio specific serum IgG4/lgE levels (baseline and after 12 months in the maintenance phase), (Wilcoxon test, $p=0.0000318)$. 


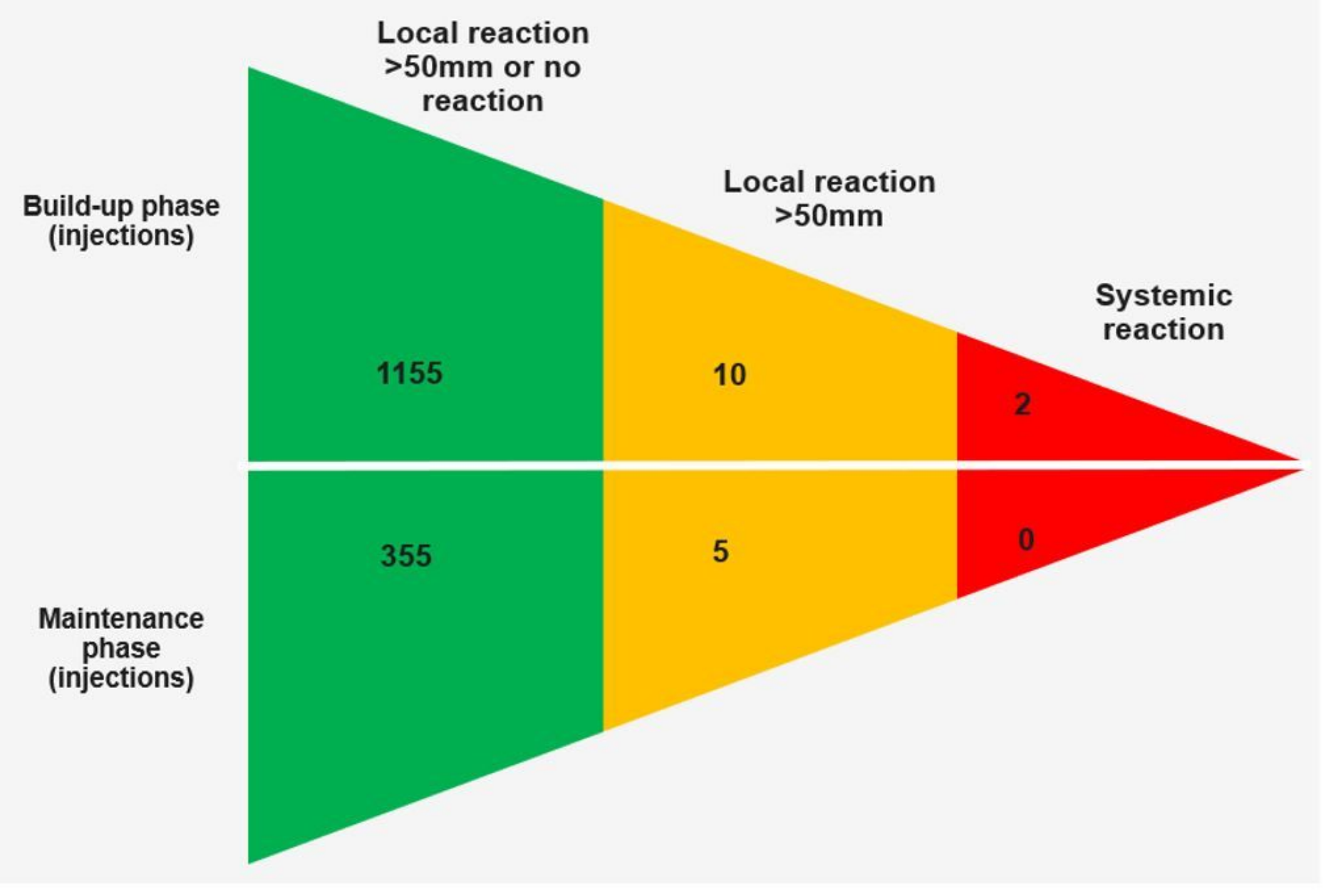

Figure 4

Number of adverse reactions (per injection) during immunotherapy according to phase and reaction type. 


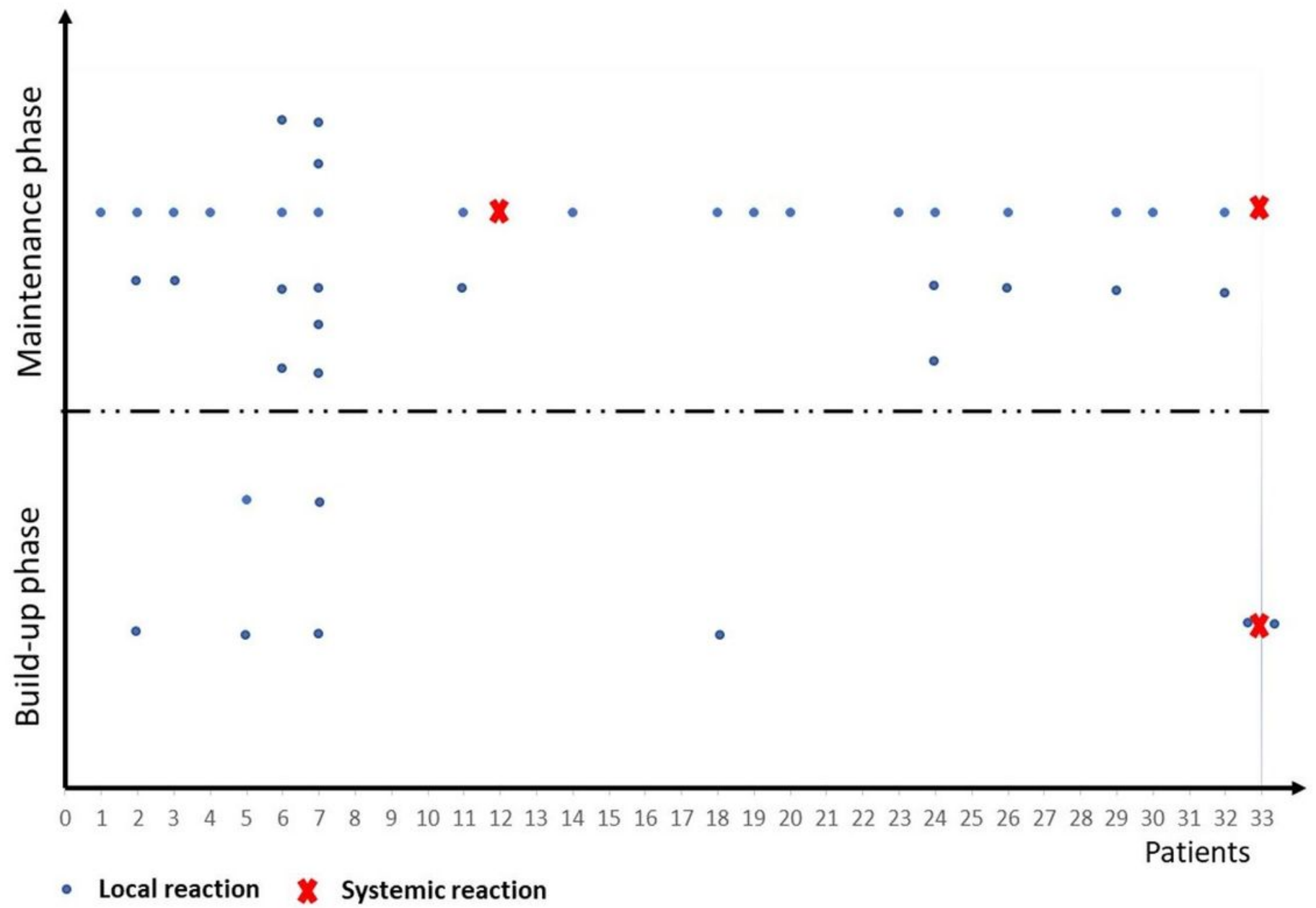

Figure 5

Distribution of accidental sting per patient during the build-up and maintenance phase according to the severity of the reaction. 